\title{
Effects of posterior amputation on the cerebral neurosecretory cells of Indian earthworm, Lampito mauritii (Kinberg)
}

\author{
Anurag Bhattacharjee ${ }^{1}$ and PS Chaudhuri ${ }^{2 *}$ \\ ${ }^{1} \mathrm{M}$.Sc in Zoology, Research Student, Department of Zoology, Tripura University, India \\ ${ }^{2}$ Professor of Zoology, Earthworm Research Laboratory, Tripura University, Suryamaninagar-799022, Tripura, India
}

\begin{abstract}
Background: Earthworms are subjected to predator attacks and agricultural practices and thus nature has gifted them the power of restoration of loss of segments. In absence of discrete endocrine gland cerebral neurosecretory system may play important role in wound healing and regeneration of lost segments.
\end{abstract}

Aim: Present aim of our paper is to study initial cytomorphological changes in the cerebral neurosecretory cells following posterior amputation in topsoil Indian earthworm species Lampito mauritii.

Method: Following posterior amputation dissected cerebral ganglia were fixed in Bouin's fluid and processed for conventional neurosecretory staining techniques: Paraldehyde Fuchsin and Chrome Alum Haematoxylin Phloxin.

Result: In contrast to control, cerebral neurosecretory cells following amputation displayed distinct cellular change such as release followed by synthesis of neurosecretion for healing up of wounds and subsequent regeneration.

Conclusion: Our preliminary study indicates cerebral neurosecretory cells are involved in healing up of wounds and subsequent regeneration in earthworm, Lampito mauritii.

\section{Introduction}

Earthworms (Annelida: Oligochaeta) are the first group of coelomates that exhibit variable degree of regeneration. The regeneration ability of 12 topsoil and 5 subsoil earthworm species have recently been studied [1] and it was concluded that the topsoil earthworm species, in contrast to subsoil species are subjected to predator attacks and agricultural practices and are equipped with the power of regeneration of lost body segments.

Lampito mauritii (Megascolecidae) is a dominant earthworm species (34\% relative abundance) of tillage ground or pasture in Tripura (India) [2]. Besides pasture soils they also inhabit cow dung pits. Because of their phytogeophagous habit (anecic) they are also considered as good waste conditioners. They are often collected by digging of soils by local people to act as fish bait. During plough in field they are subjected to loss of body segments by ploughshare and regenerate both anterior, as well as, posterior body segments [1].

In earthworms, in absence of any definite non neural endocrine gland, as found in insects, the highly vascularized central nervous system armed with abundance of neurosecretory cells (source of neurohormone) act as neuroendocrine system that controls different physiological activities including growth and regeneration. The importance of the central nervous system in the phenomenon of oligochaete regeneration has been elucidated by several classical investigators. The indispensability of the brain for regenerative growth of the anterior segments in Lumbricus terrestris was earlier experimentally established by Harms [3]. A "brain hormone" released soon after segment loss initiates the process of regeneration in Lumbricus terrestris [4]. Changes in the secretory dynamics of ventral ganglionic neurosecretory cells of earthworm Metaphire peguana during anterior regeneration were reported by Nanda and Chaudhuri [5]. Following posterior amputation in Eudrilus eugeniae there were multiple cytoplasmic alterations in the neurosecretory deep stained A cells and moderately stained $\mathbf{B}$ cells in the central nervous system [6]. Taking into consideration that Lampito mauritii, a native peregrine earthworm undergoes both anterior and posterior regeneration following amputation [1] and also that there are no reports in the literature on the neurosecretory response of the cerebral ganglia of the worm when subjected to amputation stress, we aimed to study the cytomorphological changes in the cerebral neurosecretory system in posteriorly transected earthworm, Lampito mauritii.

\section{Materials and methods}

Forty clitellate Megascolecid earthworms, Lampito mauritii (average length $14.7 \mathrm{~cm}$ ) were collected from laboratory stock culture (average

${ }^{\star}$ Correspondence to: PS Chaudhuri, Professor of Zoology, Earthworm Research Laboratory, Tripura University, Suryamaninagar-799022, Tripura, India, Tel: 9863312480; E-mail: priya_1956@rediffmail.com

Key words: earthworms, amputation, regeneration blastema, cerebral ganglia, Lampito mauritii, neurosecretory cells

Received: June 10, 2020; Accepted: June 29, 2020; Published: July 02, 2020 
room temperature $27^{\circ} \mathrm{C}$ ) and divided into 4 groups. In group-I, 10 earthworms were taken as control from where cerebral ganglia were dissected out and fixed in Bouin's for 18 hours. From the group II, III and IV, 10 individuals were taken and subjected to amputation of posterior 10 segments and considered as experimental sets. The posterior amputated earthworms were kept in earthen pots containing moisturized field soils. The cerebral ganglia of the experimental earthworms from group II, group III and group IV were dissected by sterile blade after 24, 48 and 72 hours of the posterior amputation and were fixed in Bouin's fluid for 18 hours. Both control and experimental tissues were dehydrated in graded alcohol, cleared in xylene and embedded in paraffin wax $\left(58-60^{\circ} \mathrm{C}\right)$. Serial transverse sections $(7 \mu \mathrm{m})$ were cut and stretched over clean glass slides. The sections were stained with simplified Aldehyde Fuchsin stain [7] and Gomori’s Chrome Alum Haematoxylin Phloxin following acid permanganate oxidation [8].

The nucleocytoplasmic (NP) ratios of the neurosecretory cells (10 cells of each type) were determined by measuring the maximum diameter of the perikaryon, as well as, the nucleus. Palcovit's formula $\left(\mathrm{V}=\pi / 6 \times \mathrm{LD}^{2}\right)$ has been applied for calculation of nucleus and cell volume [6]. The average value of the ratio $\mathrm{Vn} / \mathrm{Vc}-\mathrm{Vn}(\mathrm{Vn}=$ nuclear volume, $\mathrm{Vc}=$ cell volume) has been considered to assess the neurosecretory activity.

\section{Results}

\section{Behavioral changes}

Following amputation of 10 posterior most body segments in $L$. mauritii, wave of muscular contraction along their body were recorded. Coelomic fluid from the body was ejected out. Restless movement of the worm persisted for a short period of about 30 minutes. Healing up of wounds at the site of amputation was recorded after 24 hours and regeneration blastema appeared within 48 to 72 hours of posterior amputation (Figure 1).

\section{Histomorphic changes in neurosecretory system \\ Control}

Frontal sections of cerebral ganglia of control earthworms had thick cortical tier of neurosecretory cells of two categories, deep stained A cells and lightly or moderately stained $\mathbf{B}$ cells (Figure 2a and b). Small
A cells occupied the outer cortical tier and had colloidal secretion (neurosecretory materials) and large $\mathbf{B}$ cells lie in between $\mathbf{A}$ cells (Figure 2a) and inner fibrous neuropile (medulla). In fact, fibrous neuropile is made up of axons emerging from neurosecretory cells as well as ordinary neurons. Neuropile is distributed with blood capillaries (Figure 2b). Both A and $\mathbf{B}$ neurosecretory cells displayed distinct cycle of secretion in the cerebral ganglia of control earthworms. Peripheral margin of neuropile with accumulation of neurosecretion through axonal transport is considered as "zone of accumulation" (Figure 2a). The perineurium (outer neural sheath of cerebral ganglia) showed scanty distribution of neurosecretory material.

\section{Experimental}

\section{Group - I: (24 hours of amputation)}

Following 24 hours of amputation there was drop in the number of $\mathrm{AF}^{+} \mathbf{A}$ cells (Figure 3). Cell and nuclear diameter were greatly reduced in A type cells (Table 1) due to depletion of neurosecretory material. A few $\mathbf{A}$ cells had colloidal secretion in the perikarya, as well as, in the axon hillock region.

Axonal transport was visualized from few A type cells (Figure 3). The $\mathbf{B}$ cells had moderate to intense depletion of neurosecretory material. The neurosecretory cells irrespective of types had axon oriented nuclei. Both the cell and nuclear diameter irrespective of neurosecretory cell types declined (Table 1). Zone of accumulation was devoid of any secretory inclusions.

In contrast to control, nucleocytoplasmic indices (NPI) reduced significantly $(\mathrm{p}<0.05)$ in both $\mathbf{A}$ and $\mathbf{B}$ neurosecretory cells (Table 1$)$.

\section{Group -II: (48 hours of amputation)}

In general there was a great increase in the number of $\mathbf{A}$ cells beneath the perineurium with elevation in staining intensity especially in the postero-lateral part of the cerebral ganglia (Figure 4). Cell diameter of the B type cells increased to a greater extent with marginal accumulation of $\mathrm{AF}$ positive secretion showing the process of axonal transport (Figure 4). Perineurium, neuropile in general and zone of accumulation in particular were richly distributed with $\mathrm{AF}+$ neurosecretory materials (Figure 4).

Table 1. Showing effects of amputation stress on the cerebral neurosecretory cells of Indian earthworm, Lampito mauritii

\begin{tabular}{|c|c|c|c|c|c|c|c|c|}
\hline \multirow[b]{3}{*}{ Experiments } & \multicolumn{8}{|c|}{ Cerebral ganglion (Brain) } \\
\hline & \multirow[b]{2}{*}{$\begin{array}{l}\text { Mean cell } \\
\text { diameter }(\mu \mathrm{m}) \\
\pm \mathrm{SE}\end{array}$} & \multicolumn{3}{|l|}{ A type cell } & \multicolumn{4}{|l|}{ B type cell } \\
\hline & & $\begin{array}{l}\text { Mean nuclear } \\
\text { diameter }(\mu \mathrm{m}) \\
\pm \mathrm{SE}\end{array}$ & $\begin{array}{l}\text { NP indices } \\
\pm \mathrm{SE}\end{array}$ & Cell characteristics & $\begin{array}{l}\text { Mean cell } \\
\text { diameter }(\mu \mathrm{m}) \\
\pm \mathrm{SE}\end{array}$ & $\begin{array}{l}\text { Mean nuclear } \\
\text { diameter }(\mu \mathrm{m}) \\
\pm \mathrm{SE}\end{array}$ & $\begin{array}{l}\text { NP } \\
\text { indices } \\
\pm \mathrm{SE}\end{array}$ & Cell characteristics \\
\hline Control & $12.38 \pm 0.42$ & $6.43 \pm 0.21$ & $\begin{array}{l}0.12 \pm \\
0.008^{\mathrm{a}}\end{array}$ & $\begin{array}{l}\text { Distinct secretory cycle in deep } \\
\text { stained AF+ neurosecretory } \mathbf{A} \\
\text { cells. Margin of the neuropile } \\
\text { shows accumulation of AF+ } \\
\text { granules. }\end{array}$ & $12.94 \pm 0.35$ & $8.81 \pm 0.41$ & $\begin{array}{l}0.27 \pm \\
0.025^{\mathrm{a}}\end{array}$ & $\begin{array}{l}\text { Distinct secretory cycle in } \mathbf{B} \text { type } \\
\text { cells. }\end{array}$ \\
\hline $\begin{array}{l}24 \text { hours of } \\
\text { amputation }\end{array}$ & $8.31 \pm 0.36$ & $3.32 \pm 0.17$ & $\begin{array}{l}0.05 \pm \\
0.006^{b}\end{array}$ & $\begin{array}{l}\text { Drastic drop in number of A type } \\
\text { cells. NP indices in neurosecretory } \\
\text { cells declined. }\end{array}$ & $11.63 \pm 0.36$ & $6.07 \pm 0.17$ & $\begin{array}{l}0.13 \pm \\
0.008^{b}\end{array}$ & $\begin{array}{l}\text { B cells show moderate to intense } \\
\text { depletion of neurosecretory material. } \\
\text { NPI significantly reduced. }\end{array}$ \\
\hline $\begin{array}{l}48 \text { hours of } \\
\text { amputation }\end{array}$ & $7.64 \pm 0.34$ & $4.087 \pm 0.10$ & $\begin{array}{l}0.14 \pm \\
0.019^{\mathrm{a}}\end{array}$ & $\begin{array}{l}\text { Increase in number of } \mathbf{A} \text { type cells } \\
\text { and axonal transport recorded. }\end{array}$ & $15.16 \pm 0.53$ & $6.99 \pm 0.24$ & $\begin{array}{l}0.09 \pm \\
0.008^{\mathrm{c}}\end{array}$ & $\begin{array}{l}\text { Appearance of neurosecretory } \\
\text { material in the cell body of } \mathbf{B} \\
\text { cell. Neuropile charged with } \\
\text { neurosecretory material. Axonal } \\
\text { transport from } \mathbf{B} \text { cell. }\end{array}$ \\
\hline $\begin{array}{l}72 \text { hours of } \\
\text { amputation }\end{array}$ & $8.266 \pm 0.26$ & $4.127 \pm 0.18$ & $\begin{array}{l}0.11 \pm \\
0.015^{\mathrm{a}}\end{array}$ & $\begin{array}{l}\text { Visual increase in cell number } \\
\text { of } \mathbf{A} \text { cells with accumulation of } \\
\text { secretion. }\end{array}$ & $14.23 \pm 0.34$ & $8.10 \pm 0.39$ & $\begin{array}{l}0.19 \pm \\
0.022^{\mathrm{d}}\end{array}$ & $\begin{array}{l}\text { Visual increase in cell number. } \\
\text { Absence of AF+ secretory granules } \\
\text { in neuropile }\end{array}$ \\
\hline
\end{tabular}

Values represent range \& mean \pm SE; dissimilar letters in the vertical column indicate significant difference at $5 \%$ level of significance. 
In contrast to the 24 hours of amputated worms, the NPI of $\mathbf{A}$ cells increased and $\mathbf{B}$ cells decreased significantly $(\mathrm{p}<0.05)$ (Table 1$)$.

\section{Group -III: (72 hours of amputation)}

There were visual increase in the number of neurosecretory cells irrespective of their types along with accumulation of $\mathrm{AF}^{+}$secretory inclusions (Figure $5 \mathrm{a}$ and $\mathrm{b}$ ).The $\mathbf{A}$ type cells had axon oriented nuclei and showed the process of axonal transport (Figure 5a). Distinct secretory cycles were recorded in both $\mathbf{A}$ and $\mathbf{B}$ cells like those of the control. The moderately stained $\mathbf{B}$ cells maintained larger cell body with rise in the nuclear diameter compared to 24 hours and 48 hours of amputation (Table 1). There was almost disappearance of AF+ secretory granules from the neuropile.

Although there was no significant deviation in the NPI in the A cells, those in the $\mathbf{B}$ cells increased significantly $(\mathrm{p}<0.05)$ compared to cerebral neurosecretory cells of 48 hours of posterior amputation (Table 1).

\section{Discussion}

Endocrine role of caudal regeneration in earthworm has been elucidated $[6,9,10]$. The topsoil species, Lampito mauritii can regenerate both anterior, as well as, posterior body segments if subjected either to anterior or posterior amputation [6]. They further reiterated that

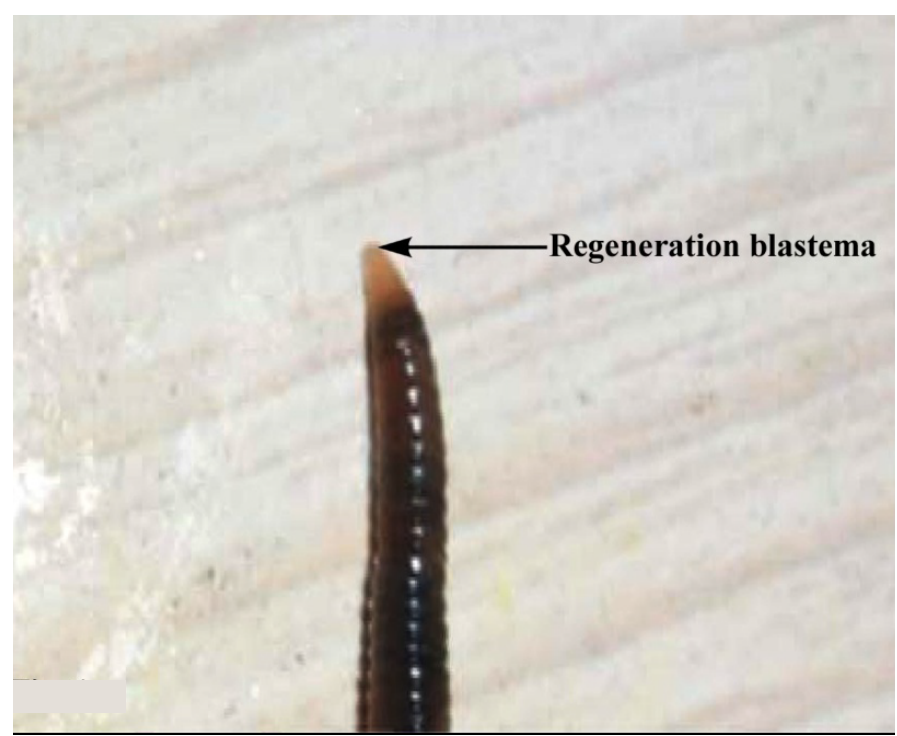

Figure 1. Showing the regeneration blastema in Lampito mauritii following 72 hours of posterior amputation

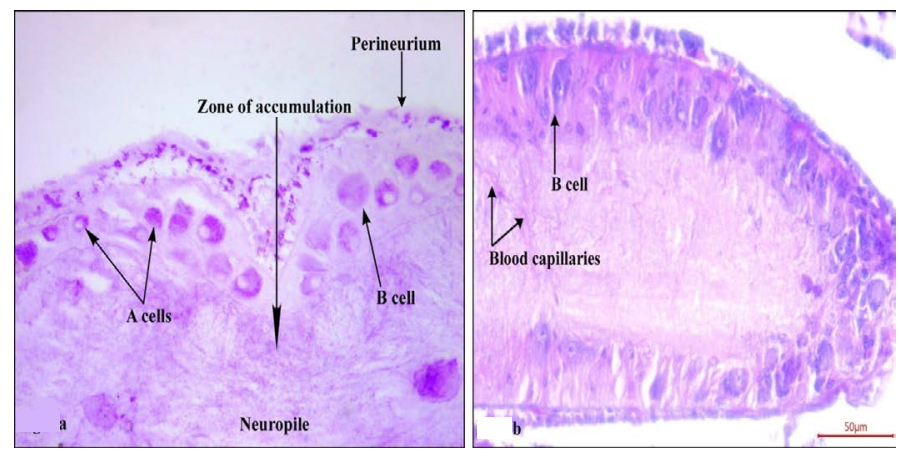

Figure 2. Frontal section showing distribution of AF and CAHP positive neurosecretory cells along with 'zone of accumulation' (2a) and blood capillaries (2b) in the cerebral ganglia of control earthworms (X400)

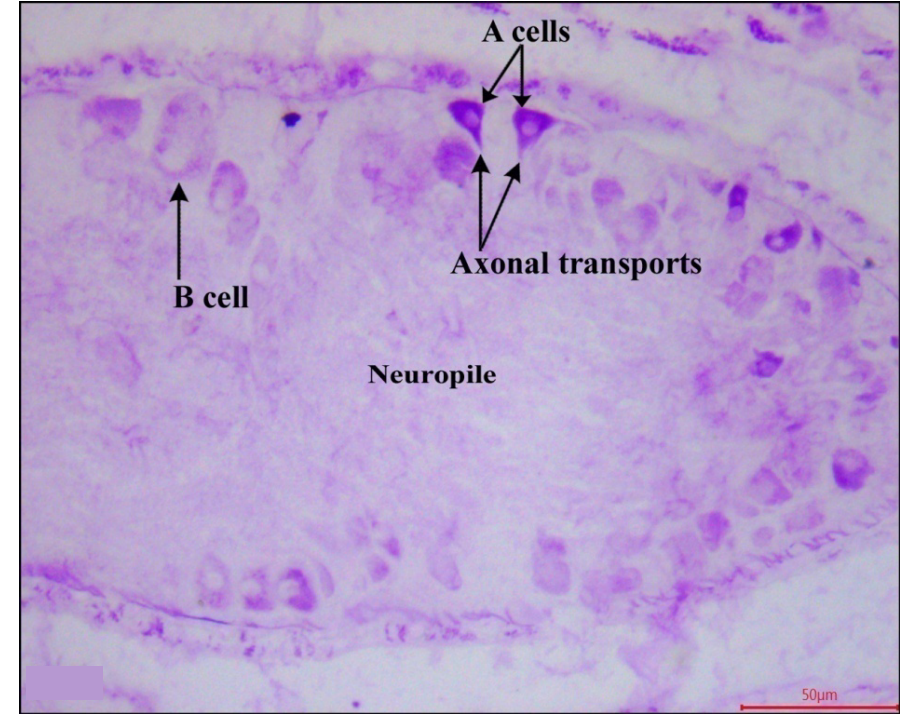

Figure 3. Frontal section showing distribution of AF positive neurosecretory cell along with 'axonal transport' in the cerebral ganglia of 24 hours amputated earthworms (X400)

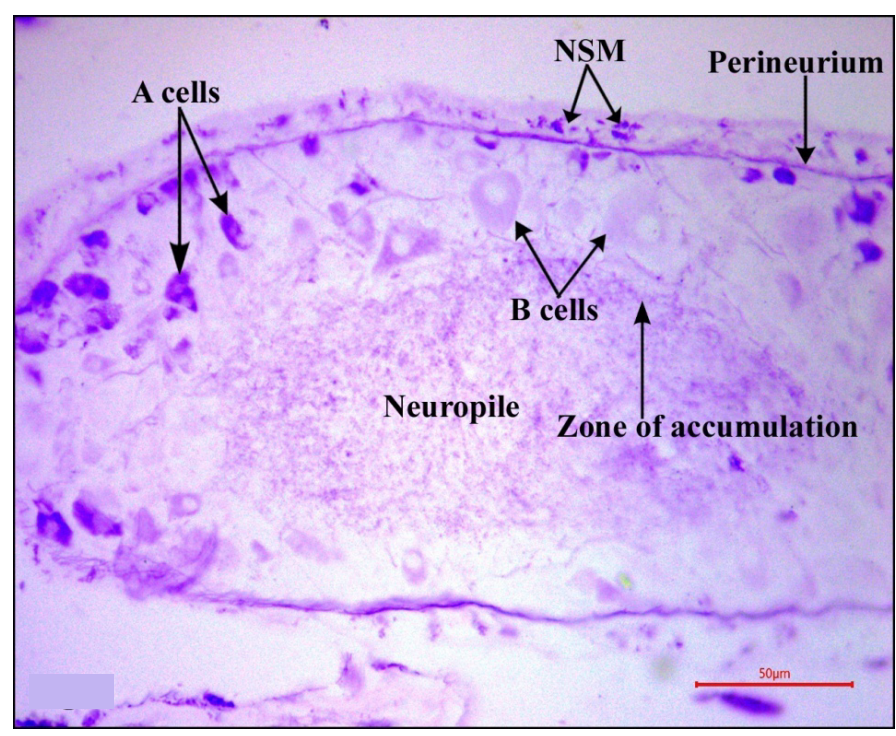

Figure 4. Frontal section showing distribution of AF positive A and B neurosecretory cells along with neurosecretory material (NSM) in the cerebral ganglia of 48 hours amputated earthworms (X400)

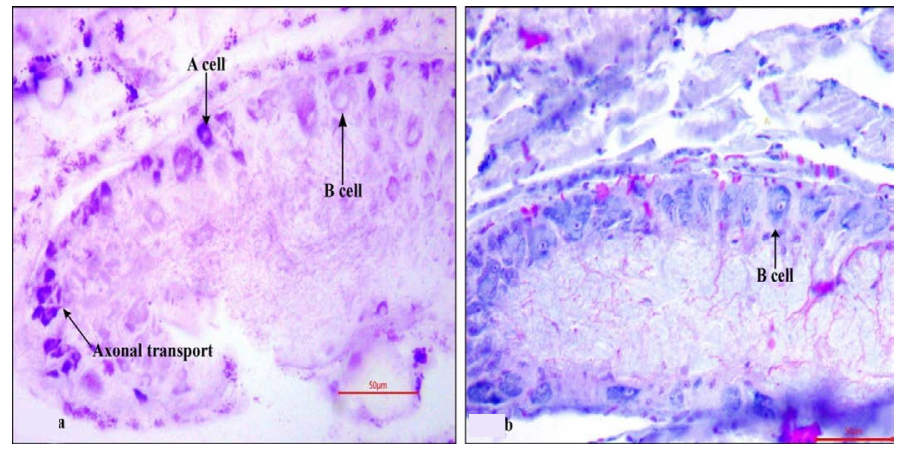

Figure 5. Frontal section showing distribution of AF and CAHP positive neurosecretory cells. AF positive A type cell with axonal transport (5a) is visible in the cerebral ganglia of 72 hours amputated earthworms (X400) 
under experimental condition, in the same species, anterior transected five segments were restored within 15 days but the same numbers of amputated posterior body segments regenerated within 18 days which indicates that anterior regeneration is much faster than posterior regeneration.

Cytomorphological studies reveal a change in structure and secretory dynamics of the cerebral neurosecretory cells of $L$. mauritii following posterior amputation. Induction of such stimulation was probably propagated through the ventral nerve cord. Amputation induced changes in the cerebral neurosecretory cells are most conspicuous 24 hours after amputation. But thereafter almost uniform cellular changes are noticed in the cerebral ganglia at 48 hours and 72 hours after amputation. Marked depletion of neurosecretion in the neurosecretory cells following 24 hours of posterior amputation suggests an efferent release of cerebral neurohormone for healing up of wounds in response to the afferent stimulus impinged through the loss of segments. Increase in the number of deep stained $\mathbf{A}$ cells with accumulation of colloidal secretion and rise in NP indices are indicative of an accentuation in the synthetic activity of these cells following 48 hours of amputation. Distinct secretory cycle in the $\mathbf{B}$ cells along with axonal discharge of AF positive secretion in the the zone of accumulation of the neuropile indicate involvement of the $\mathbf{B}$ cells of the cerebral ganglia to overcome generalized stress action.

Rich accumulation of neurosecretory materials in both $\mathbf{A}$ and $\mathbf{B}$ neurosecretory cells and disappearance of neurosecretory materials from neuropile in the cerebral ganglia of 72 hours of posterior amputation indicates utilization of neurosecretory materials and functional involvement of neurosecretory cells in general and $\mathbf{B}$ cells in particular under altered physiological conditions of the worms during their healing up wounds and subsequent regeneration. Recently uniform changes in synthesis, storage and release cycle of neurosecretory cells were recorded up to 96 hours of post amputation in the central nervous system of South African vermicomposting earthworm, Eudrilus eugeniae with great regenerating potential by Banik and Chaudhuri $[1,6]$. Functional involvement of moderately stained cells (B cells) in the ventral nerve cord of Metaphire peguana during cephalic regeneration was earlier reported by Nanda and Chaudhuri [5]. In Eudrilus eugeniae, it has been suggested that posterior regeneration is under the joint influence of 'regeneration inhibiting factors' secreted by cerebral ganglia and 'regeneration promoting factors' released from the ventral nerve cord [6]. Nervous system is essential for regeneration because if part of the nerve cord is removed from the adjoining transected portion of earthworm, regeneration soon stops [11].

The chloragogen cells present in the coelomic fluid are important in the earthworm regeneration, because there is a mass migration of these cells to the site of wound after part of the earthworm is cut off [11]. A 'critical inhibitor voltage theory' suggested that the formation of new segments continues at the tip of the earthworm until a critical voltage is built up [11]. Recent research indicates that in oligochaetes engrailed and orthodenticle class genes are expressed during their regeneration [12].

Differential expression of actin genes during tissue regeneration in Lumbricus terrestris was reported by Helmes and Cocker [13]. Although the phenomenon of regeneration has attracted considerable attention, scientists still lack adequate knowledge on the physiology of earthworm regeneration [11].

\section{Acknowledgment}

Authors thankfully acknowledge Prof. B. K. Agarwala (Ex. Head of Zoology) for the kind cooperation and constant encouragement during carrying out of our research. This research was supported by internal grant from the university.

\section{Conflict of interest}

In the submission of research paper, there is no conflict of interest between the first author, Anurag Bhattacharjee and the second author (corresponding author), Prof. P.S. Chaudhuri. Both the authors jointly contributed to this paper. The first author carried out the research during his M.Sc dissertation and the second author guided the research and corrected the manuscript.

\section{Statement of ethical approval}

Tripura University Animal Ethics Committee allows research works on earthworm species as they are cultured well under laboratory conditions.

\section{References}

1. Banik D, Chaudhuri PS (2017) Regeneration ability in seventeen top soil and sub soil earthworm species. J Environ Biol 28: 393-399.

2. Debbarma B, Chaudhuri PS (2019) Earthworm communities under Pasture Ecosystems in Tripura, India. International Journal of Ecology and Environmental Sciences 45: 179-190

3. Harms WR (1948) Ueber ein inkretorisches cereoralorgan bei lumbriciden sowie 'Beschreibung eines verwandten Organs bei drei neuen Lycatis. Arten. Arch Entw Mech Org 143: 332-346.

4. Chapron C, Chapron J (1973) Induction de la regeneration posterior chez les Annelide dn genere Lumbricus. C R Acad Sci Paris 276: 2691-2694.

5. Nanda DK, Chaudhuri PS (1982) The effect of cephalic transection on the micro morphological changes in the ventral nerve cord- neurosecretory system of earthworm Metaphire peguana (Rosa, 1890) during anterior regeneration. Proc Indian Acad Sci (Anim Sci) 91: 381-389.

6. Banik D, Chaudhuri PS (2016) Neuroendocrine control of posterior regeneration in Tropical Earthworm Eudrilus engeniae (Kinberg). Journal of Life Sciences 10: 289-297.

7. Cameron ML, Steele JE (1959) Simplified aldehyde fuchsin staining of neurosecretory cells. Stain Technol 34: 265-266.

8. Bargmann W (1949) Über die neurosekretorische Verknüpfung von Hypothalamus und Neurohypophyse. Z Zellforsch 34: 610-634.

9. Hanumante MM (1975) Some aspects of physiology of Indian Earthworm. Ph.D Thesis, Marathwada University, Aurangabad, (M.S.) India,

10. Bedre RV, Kulkarni V, Kulkarni GK (1988) Caudal regeneration as a function of neuroendocrine manipulation in the earthworm, Metaphire houlleti Perrier. Proc Ind Natn Sci Acad B 54: 443-450.

11. Edwards CA, Bohlen PJ (1996) Biology and Ecology of Earthworms. Chapman and Hall, London: 1-426.

12. Bely AE, Wray GA (2001) Evolution of regeneration and fission in annelids: Insights from ingrailed and orthodenticle gene expression. Development 128: 2781-2791

13. Helmes AJ, Cocker JS (2010) Variability of actin gene expression during tissue regeneration of the earthworm Lumbricus terrestris. J North Carolina Acad Sci 20: $138-143$

Copyright: (C2020 Bhattacharjee A. This is an open-access article distributed under the terms of the Creative Commons Attribution License, which permits unrestricted use, distribution, and reproduction in any medium, provided the original author and source are credited. 